\title{
PROLETARIATETS KULTURHISTORIE
}

\author{
anmeldelse af \\ Otto Rühle: Illustrierte Kultur- und Sittengeschichte des \\ Proletariats, Bd. 1, Verlag Neue Kritik 1970. \\ Otto Rühle: Illustrierte Kultur- und Sittengeschichte des \\ Proletariats, bd. 2, Focus Verlag, 1977. \\ Originaludgave.
}

I den på så mange måder så deprimerende krisesituation er der også opmuntrende momenter: den usikkerhed og det opbrud som krisens forandring af de samfundsmæssige livsbetingelser har frembragt har naturligvis også præget den vesteuropæiske socialistiske venstrefløj, men har $i k k e$ resulteret i en $\emptyset$ get underkastelse under autoritære, centralistiske avantgardepartier. Tværtimod forholder det sig omvendt, man kan iagttage en stadigt $\emptyset$ get socialistisk kritik af sådanne partidannelser og de dermed forbundne politikforståelser og socialisme-opfattelser, en stadig mere omfattende problematisering af deres anvendelighed i revolutionære processer, samt deres praktiske fallit i de sociale kampe.

Da også hovedparten af de socialistiske skribenter og teoretikere ifølge sagens (og det vil sige kapitalismens) natur er »åndsarbejdere «, er det klart, at den teoretiske del af opgøret med ovennævnte opfattelser tager form af disse åndsarbejderes selvkritik samt at diskussionen af forholdet mellem »intellektuelle og arbejderklassen« tildeles langt st $ø$ rre betydning i litteraturen end problemets
"Det, der har været historie for eliterne, har altid været arbejde for masserne«.

status i en virkelig revolutionær bevægelse berettiger til. Det vigtigste er imidlertid, at gennem denne afklaringsproces fremvokser der et alternativ til de »intellektuelles « umulige valg mellem en opfattelse af sig selv som hhv. arbejderklasens ledere eller dens selvudslettende halehæng: en forståelse af sig selv som en mulig, ligeværdig del af en kommende revolutionær bevægelse og som en specifik - og aktuelt på mange måder privilegeret - del af arbejderklassen med egne legitime emancipationsinteresser i socialismen.

For de socialistiske intellektuelle med et sådant udgangspunkt bliver den centrale teoretiske problemstilling spørgsmålet om emancipationens samfundsmassige betingelser. Dette altomfattende og komplicerede problem lader sig naturligvis ikke bringe på en simpel formel der lader sig løse gennem f.eks. den »rigtige« kriseforståelse eller den korrekte organisations-konception, men må udvikles gennem en omfattende kollektiv afklaringsproces på mange forskellige niveauer og med mange forskellige indfaldsvinkler - hvor vi atså i 
dette nummer af KURASJE har søgt at skitsere nogle. På denne baggrund er det muligt at perspektivere bestemte strømninger i den aktuelle teoriudvikling, som f.eks. »socialisationsteorierne« og teorierne om »hverdagslivet «. Der er jo en snæver sammenhæng mellem de antileninistiske strømninger i de socialistiske bevægelser og den marxistiske teoretiske interesse i sådanne problemstillinger: afviser man på den ene side at forholde sig fra oven til arbejderklassen, mens man på den anden side selv er »mellemlag «, »åndsarbejder«, kan denne modsigelse få sin mest simple bevægelsesform i en »oplysningsstrategi« overfor arbejderklassen - man kan bidrage til udviklingen af arbejderklassens selvbevidsthed ved teoretisk at belyse de samfundsmæssige betingelser for, hvorfor den er, som den er. Nogle af de problemer og implicitte antagelser der er forbundet med en sådan strategi vil jeg komme lidt ind på senere i diskussionen af Otto Rühle, der netop selv repræsenterer tilsvarende positioner, omend med et andet historisk/samfundsmæssigt udgangspunkt. Imidlertid udpeger en sådan »oplysningsstrategi« socialisations- og opdragelsesprocesser som centrale interessefelter og de har da også en høj prioritering i »Kulturhistorien«. Ligeledes må denne selv være tænkt som middel i en socialistisk opdragelse af proletariatet, hvilket tydeligt præger hele dens udformning og oplæg.

Hensigten med at henlede opmærksomheden på Rühlers analyser af »hverdagslivet « og »socialisationen« er ikke at præsentere en ny grydeklar teori, der blot kan smækkes ned over de aktuelle forhold. Derimod vil vi måske kunne afdække noget af vore egne standpunkters logik og konsekvenser hvis vi indløste K. Korsch' krav om at anvende marxismen på analysen af marxismens egen udvikling - og for et sådant projekt forekom- mer Rühles produktion af en lang række grunde at være uhyre relevant $\mathrm{i}$ vor aktuelle situation. ${ }^{1}$ Selvom det jo ikke er det jeg bilder mig ind at gøre her.

Otto Rühle (født 1874-død 1943) personificerer en lang række erfaringer fra den europæiske arbejderbevægelses allervigtigste faser: fra den »gamle arbejderbevægelse« i II. internationales periode, over verdenskrigen, revolutionerne i Europa og Rusland, frem til arbejderbevægelsernes udslettelse gennem nazismen og 2. verdenskrig. I disse forløb har Rühle spillet en ikke ubetydelig rolle både som aktivist og teoretiker. At han trods dette stort set er forblevet ukendt, skyldes at hans personlige udvikling falder sammen med den »venstre-radikalisme « som de institutionaliserede arbejderbevægelser altid har søgt at bekæmpe og hvis eksistens er blevet undertrykt og fortiet af disse institutioners teoretikere og historieskrivere. ${ }^{2}$

Rühle var foredragsholder, redaktør, vandrerlærer i det tyske førkrigs Socialdemokrati og blev senere for en periode rigsdagsmedlem, hvor han sammen med Karl Liebknecht som den første stemte mod krigsbevilling i 1915. Herfra udviklede han sig i stadig mere venstreradikal retning, brød sammen med Spartakusbund ud af socialdemokratiet, men udviklede sig under indtryk af revolutionsbegivenhederne i 1918-19, hvor han var yderst aktiv, til en af de mere konsekvente forkæmpere for råds-kommunismen. Følgelig hørte Rühle som teoretiker til de allerførste der gjorde opmærksom på de autoritære tendenser $\mathrm{i}$ arbejderbevægelserne (kritik af leninismen) og i samfundene (kritik af sovjetrusland efter ophold der allerede fra 1920, kritik af facismen). ${ }^{3}$

Rühles to meget store bøger om proletariatets »Kultur- und Sitten/sæd og skik/Geschichte « (over 1.000 sider i stort format) er arbejderbevagelsernes histo- 
rie på en helt anden måde, end den sædvanlige organisations-, fører-, og teorihistorie, som klassens førende lag og deres venner har skrevet om og for hinanden. Rühles »kulturhistorie« er de anonymes historie, det daglige livs og dets kampes, dets fremskridts og utilstrækkeligheders historie. Hvis August Strindberg har ret $\mathrm{i}$, at historie er »Beretningen om det forgangne, for såvidt det fremstilles $i$ et for overklassen fordelagtigt lys « - så er Rühles kulturhistorie »anti-historie«. Den er et veloplagt, hadefuldt angreb på overklasser og eliter af alle slags. »Kulturhistorien« ligger indenfor rammerne af den - ikke spor omfattende - »marxistiske« tradition, som Engels grundlagde med »Die Lage der arbeitenden Klasse in England $\ll$.

Inden jeg overgår til en gennemgang af »kulturhistorien « - jeg intenderer ikke her nogen systematisk kritik af den, hvad der for såvidt godt kunne bruges, men vil snarere præsentere nogle af dens synsvinkler i relation til aktuelt diskuterede problemer - vil jeg understrege betydningen af, at det er en illustreret kulturhistorie. Bøgerne er nemlig fulde af gode billeder (selvom disse ikke altid er ligegodt gengivet), der mange steder virkelig uddyber tekstens mening. Da bøgerne jo er skrevet for arbejdere, ville det være meningsløst af Rühle at illustrere med billeder af det, de kun kender alt for godt. Det betyder at han i vidt omfang har benyttet forskellige kunstneres kritiske afbildinger, istedet for mere »dokumentarisk « materiale. Gennem en lang række fremragende kunstneres (f.eks H. Zille, Daumier, Groz, K. Kollwitz, Steinlen, og mange flere) ofte humoristiske, solidariske kritik, gennem deres forholden sig til den verden de skildrer, får vi meget mere at vide, end gennem de »dokumentariske« fotos, som virker - og jo også er - kunstige og stive opstillin- ger. Dermed er der en indholdsmæssig sammenhæng mellem tekst og billeder i »kulturhistorien « $\mathrm{i}$ helt andre dimensioner end i det traditionelle mønster, hvor tekstens beskrivelse af en spade illustreres med billedet af en spade. Hvad er det mon der stadigvak får socialister - når de skal bruge illustrationer - til at elske den røvtriste, platromantiske »socialrealisme «, hvor arbejdere skal gøres til »arbejdets helte« og socialismen skal se ud som en samfundsomfattende spejderbevægelse?

Rühles hensigt er at overbevise, at oplyse, derfor må han ikke blot postulere, men argumentere - revolutionen forudsætter indsigt. Proletariatet skal hverken søge borgerskabets anerkendelse og opbakning eller blot revoltere mod det, hverken tilpasse, borgerliggøre sig, eller tomt protestere, men overvinde, gennem revolution afskaffe selve det samfundsmæssige klassesystem. »Revolutionen er ikke en enkeltstående magthandling der ændrer verden, derimod en historisk proces af kortere eller længere varighed, hvis opgave det er, at orientere kulturen efter et nyt princip.«(I:30).

Denne nye kultur vil omfatte behovsøkonomi, kollektiv ejendom, klasseløshed, rådssystem, lighed mellem køn og generationer, kærlighedsægteskab, medmenneskelighed - men er foreløbig blot et postulat. »Idag gælder det derfor om at påvise: Hvor langt er proletariatet kommet på vejen mod dette mål? Hvor vidt har det opgivet tilpasnings-taktikken til sin borgerlige omverden? Hvor vidt har det været istand til at gøre sin protest frugtbar for klassekampen? Hvor vidt er overvindelsen af den borgerlige kultur lykkedes? Hvor langt har det udviklet begyndelse og ansats til nye kulturelle orienteringer? Det proletariske menneske står stadig i skæringspunktet af en vanskelig historisk situation. Fortiden 
belaster det med overleveringens lænker. Nutiden udfordrer det til kampe. Fremtiden forlanger den sociale revolution af det.«(I.30).

Disse spørgsmål søger Rühle at besvare gennem en omfattende historisk gennemgang af såvel de aktuelle forhold som disses forhistorie. Denne gennemgang er opdelt i 4 hovedafsnit: Arrbejdets forbandelse, Miljøets rædsler, Fortidens skygger, Veje til befrielse, som hver især kort skal kommenteres, og udvalgte dele af indholdet resumeres.

\section{Arbejdets forbandelse}

Rühle tager udgangspunkt i den »oprindelige akkumulation «, anvender materiale der belyser forholdene i hele Europa, viser småbøndernes fordrivelse fra jorden, hvorledes de jordløse bønder, tiggere, landstrygere med vold og magt gøres til lønarbejdere. Herefter behandles udbytningsmetoderne, metoderne til slavegørelse af arbejderne, kooperationsformerne fra håndværk over simpel kooperation, manufaktur til industri. For de der er bekendte med Marx' Kapitalen er der knap så meget nyt her, men Rühle forklarer og belærer os utrætteligt hvordan det virkeligt er - teorien er her magtfuld agitation. Som f.eks. her hvor det drejer sig om betegnelserne »arbejdstager« og »arbejdsgiver« for hhv. arbejder og kapitalist: »Disse betegnelser indeholder i begge tilfælde en forfalskning af de faktiske relationer. Kapitalisten giver intet arbejde, men kun lejlighed til at arbejde. Herfor beslaglægger han resultatet af det arbejde, arbejderen har ydet. Han skulle så logisk set hedde arbejdstager. Og arbejderen modtager intet arbejde, han benytter blot en lejlighed til at arbejde. Det arbejde han yder, afgiver han i skikkelse af varer til kapitalisten. Han fortjente betegnelsen arbejdsgiver.« (bd I, s. 126).
Rühle behandler herefter »Udbytningens afgrunde«, kvindearbejde, børnearbejde, hjemmeindustri, forlagssystem, osv. og fortsætter med et afsnit om »Opvågnen som klasse « der beskriver arbejderbevægelsernes første organisering og tilblivelsesproces, den franske revolution, chartisbevægelsen i England, Sismondi og Blanqui i Frankrig, Weitling o.a. i Tyskland, Lasalle, Bebel, 1. Internationale, Gothaprogrammet, fagforeningsbevægelserne i Tyskland og Frankrig, mm. Disse afsnit virker ikke så meget gennem de oplysninger man får gennem dem - i hvertfald ikke hvis man er nogenlunde bekendt med disse begivenheder som er blevet mere omfattende belyst gennem den nyere forskning men snarere gennem Rühles evne til at strukturere og ikke mindst perspektivere disse store forløb, vise dem som små dele af en stor proces - det revolutionære mål og klassekampen hen imod det, er nærværende overalt i fremstillingen. Originalitet og nytænkning er der derimod i de mere »socialisationsteoretiske« afsnit, f.eks. i afsnittet om »Hindringer for solidaritet.« (1: 245-295).

Opdragelsen til solidaritet og dannelsen af enhed i arbejderklassen er ifølge Rühle en proces, der tager årtier, århundreder. Arbejderklassens kollektivistiske princip fandt oprindeligt sit udtryk $\mathrm{i}$ fagforeninger, politiske sammenslutninger og kooperative bevægelser. Men heller ikke den klassebevidste proletar ophører jo med at være en del af det borgerlige samfund. »Som påtvunget medlem af det borgerlige samfund tager proletarerne - trods sin klassemæssige bekendelse til det kollektivistiske princip - nødvendigvis del i det individualistiske princip. Han er så at sige en spaltet personlighed. Som klassemedlem af proletariatet er han kollektivist, men som enkeltproletar $\mathrm{i}$ det borgerlige samfund bliver han 
individualist. Ja gennem sin personlige $\emptyset$ konomiske situation bliver han til stadighed gjort vaklende og fors $\emptyset$ ger at anvende det individualistiske princip. For idet han sælger sin arbejdskraft som vare for at leve af dens indkomst, deltager han som varesælger, som funktionær i en grundlæggende proces i den borgerlige $\varnothing$ konomi.« (I: 250). Herudfra søger Rühle at vise, hvorledes den generelle klassemodsætning reproduceres som modsætninger mellem de enkelte mennesker. ${ }^{4}$ Alle vil være bourgeois, ingen vil være proletar - hvergang en eller anden opnår en overlegenhedsposition, forholder han sig som om han var bourgeois.

Den enkelte proletar bliver således åndeligt borgerliggjort, idet han kun er istand og tilbøjelig til at indgå i forhold, der på forhånd sikrer denne overlegenhedsposition, denne bourgeois-rolle - det kan være i familien, i organisationerne, blandt kolleger, osv. I det mindste er der aldrig nogen der $\emptyset$ nsker at spille en proletarrolle!

At forholde sig solidarisk som klasse konfronteret med en anden klasse og at forholde sig usolidarisk menneske til menneske er i virkeligheden ikke nogen modsætning - den upolitiske proletar forener $\mathrm{i}$ sin person socialisten og bourgeoisen. Rühle går ud fra, at »Proletariatet eksisterer som social klasse i solidarisk enhed. Men indadtil hersker modsætninger fra menneske til menneske fra gruppe til gruppe.« (I: 258). Det der hæmmer klassekampen og solidariteten behandler Rühle her ud fra to sæt af sammenhænge, dels de gruppe-antagonismer der består mellem forskellige arbejderkategorier, dels de der udspringer af arbejderens privatliv, af bourgeoisen indeni enkeltproletaren.

Herefter følger en omhyggelig gennemgang af de modsætninger der udsprin- ger af »arbejdsverdenens hierarki«, hvorimod »privatlivets « forhold hovedsageligt behandles i bd. II. Rühle gennemgår alle de forskellige former for modsætninger: forholdet mellem faglært og ufaglært og foregriber her den senere »massearbejder-diskussion« (S. Bologna K.H.Roth - E.Lucas), viser hvordan der fra de faglærtes rækker rekruteres »mestre«, værkførere, etc. behandler problemet om elitearbejder, mønsterarbejder, »fedterøve «. »Uanset hvorledes særgrupperne på virksomheden er blevet til - så er de der, spiller en central rolle, gælder som autoritet, trykker de $\varnothing$ vrige arbejdere, forhindrer at fællesskabsforhold kommer istand.« (I: 271). Videre behandles modsætningerne mellem: nyansatte og gamle på virksomhederne, mellem lokale og »fremmede« arbejdere, (hvor f.eks. udenlandske arbejdere ikke altid udgjorde de laveste lag i hierarkiet, men derimod ofte blev importeret som »specialister «,) modsætninger til »afvigere $«$ (åndssvage etc.), mellem ungarbejdere, lærlinge og de udlærte voksne, mellem hånds- og åndsarbejdere. Rühle mener ikke disse modsætninger alene overvindes ud fra de fælles erfaringer på virksomhedsplan, selvom arbejdets kooperative karakter kan fremme en disposition til solidariske forhold. Konkurrencen og brødniddens ophævelse er heller ikke blot et problem om arbejdsorganisation, men om proletarisk opdragelse. Det er i denne forbindelse påfaldende, at Rühle ikke tænker disse problemer ind i sammenhæng med kapitalforholdets udviklingsmønstre.

To modsætningsforhold i »arbejdslivets hierarki« får særlig udførlig behandling: forholdet mellem mænd og kvinder og mellem unge og ældre, mellem generationer, - med de ældre kvinder som skæringspunkt for alle elendigheder. Med Rühles radikale opfattelse af »kvin- 
despørgsmålet« og hele hans antiautoritære og antidogmatiske indstilling kan det undre, at han ikke har vakt nogen større interesse i den aktuelle kvindebevægelse. ${ }^{5}$ Mand-kvinde problematikken behandles mere udførligt i bd. II, så her blot et karakteristisk citat som den aktuelle krise har givet aktualitet: »Kvinden hører til i hjemmet! « sådan lød borgerens visdom, ikke dengang kvinden ombyttede husholdningen med fabrikshallen, men da hun forsøgte at skaffe sig de friheder og rettigheder, der tilkom hende udfra hendes stilling som fabriksarbejderske og erhvervsaktiv.« (I: 280).

M.h.t. forholdet mellem generationerne viser Rühle dels hvorledes de yngre kan true de ældres positioner, men også hvorledes de ældres autoritære holdninger og væremåde skaber problemer for de yngre. »Hvad der blev sagt om modsætningen mandkvinde lader sig sammenlignende gentage $\mathrm{i}$ forhold til modsætningen gammel-ung: i den udtrykker klassernes generelle forhold i klassesamfundet sig, de gamle er bourgeoisen, de unge befinder sig i proletariatets rolle.« (bd. I. s. 287). Dette får også stor betydning for de forskellige arbejderorganisationer der helt er domineret af de ældre (mænd) - og herudfra begrunder Rühle nogle særlige sociale bevægelser af unge på den tid, »vandrer-bevægelsen « og »sportsbevægelsen«. Han opfatter disse proletariske ungdomsbevægelser som »Et stykke emancipation der ganske vist kan blive til skade for den totale bevægelse, hvis sport og vandring leder bort fra de egentlige mål og bliver til mål i sig selv.«(I: 294). (Afsnittet er illustreret af et billede af »marxistisk undervisning under en vandretur «: en marxist i jægerdragt og retstilling underviser de unge vandrere, der gør sig det bekvemt og kammeratligt på en skyggefuld skråning i skoven.)
På problemerne omkring dannelsen af solidaritet konkluderer Rühle, at med omvæltninger i det $\varnothing$ konomiske og sociale liv, må også omvæltninger af det indre menneske finde sted. »Ikke således, at hver enkelt søger at gennemføre forandringen på sin egen måde. Derimod således, at enhver med sit totale menneske kaster sig ud i klassekampens flod, opgiver sin privat-skæbne, lader sine tusinde små uendeligt overvurderede subjektive konflikter gå op i klassernes store sociale konflikt ... Med denne oplevelse vågner det socialistiske menneske i det proletariske menneske, frig ør ud af den borgerlige kultur den socialistiske kulturs første livskim.« (I: 295).

\section{Miljøets rædsler}

Afsnittet indledes med en omfattende gennemgang af de materielle reproduktionsbetingelser belyst med historisk materiale fra hele Europa: levestandard, ernæring, beklædning, hvor vægten i fremstillingen først og fremmest er lagt på beskrivelsen af elendigheden. Dernæst behandles boligproblemerne, de altfor små, usunde, overbefolkede lejligheder, de mange boligløse, de nat-logerende, de husvilde, herbergerne, etc. - opsummeret $\mathrm{i}$ en kritik af de individuelle familieboliger, og de problemer som en sådan boligstruktur skaber for dannelsen af klassesolidaritet. Man får her let associationer til det moderne parcelhusbyggeri, der i bogstaveligste forstand har cementeret individuelle boligformer mange år ud $\mathrm{i}$ fremtiden.

De elendige bolig- og levevilkår sættes i sammenhæng med alkoholmisbrug, der får en meget grundig behandling, hvor det sættes i sammenhæng ikke blot med de elendige sociale forhold, men også med normer om mandighed, etc. Desuden behandles de politiske kampe mod alkohol, de borgerlige og de mere prole- 
tariske afholdsbevægelser, mm. Herefter følger afsnit om prostitution, forskellige former for sexuelt misbrug og overgreb der finder sted på arbejdspladserne, bordeller, alfonseri. Selvom der efter Rühles opfattelse er sket visse fremskridt på området, fastslår han, at med det sociale problem prostitution formår det borgerlige samfund ikke at gøre op. »Det skulle da være hvis det omstødte sin sexualorden, prisgav sin ægteskabsform, ofrede sin privatejendom - altså gav afkald på sine klasseprivilegier. Men det vil og kan det ikke.« (I: 484).

Bd. 1 slutter med afsnit om sygdomme (miljø- og arbejdsmiljøbetingede) og om militarisme. Rühle mener, at det historisk er den organiserede militarisme, der har gjort tyskerne til et gennempryglet folkefærd og at proletariatet som arv efter denne militære »pædagogik « altid forventer sine foresattes knippel på ryggen og han ser proletariatets underkastelse under militærets terroristiske disciplin som indikator for dets manglende klassebevidsthed. Endelig afsluttes med et afsnit om justits og fængsler hvor særlig de forskellige strafformers $\varnothing$ delæggende virkninger gennemgås - på samme måde som det for tiden sker i diskussionen om isolations-fængsling.

\section{Fortidens skygger}

I dette afsnit behandles - udover underafsnittet »ægteskab - sexualitet - familie« som jeg nu vil referere - følgende: religion, politik, videnskab, moral, opdragelse, presse, fester og forn $\varnothing$ jelser.

Som det allerede antydes i afsnittes titel, behandles en lang række »overbygningsfænomener « her først og fremmest under synsvinkelen af at være »usamtidig « med »basis« grundlæggende dynamik, hvorfor Rühle kritiserer arbejderklassen for dens småborgerlige adfærdsformer og bevidsthed på en lang række områder. Således begrunder han det borgerlige ægteskab ud fra dets » $\emptyset \mathrm{ko}-$ nomiske« funktion, at være instrument $\mathrm{i}$ ejendoms-opretholdelsen. I dette ægteskab har manden primært en $\varnothing$ konomisk forpligtigelse, kvinden er sexuel. Men for det besiddelsesløse proletariat, hvis eksistensbetingelser er lønarbejdet, beh $\phi v e r$ den ideologi, der omgiver det borgerlige ægteskab ikke at have nogen gyldighed. »Ægteskabet kan her i høj grad være en kærligheds-pagt « (II:8). Når det i virkeligheden kun er dette i begrænset omfang, skyldes det altså, at proletariatet ikke har opgivet den ideologi, der kan føres tilbage til de sociale lag (bønder, småborgere) hvorfra det oprindeligt blev rekruteret. HVORFOR ideologien tilsyneladende har en sådan stabilitet, besvares ikke af Rühle - ligesom det heller ikke diskuteres i de nyere familieteorier, der udgår fra en lignende opfattelse. Hvorfor proletarerne står overfor ægteskabsproblemet som borgere, må derfor af Rühle først og fremmest diskuteres som et psykologisk anliggende, og den centrale tese hos ham er, at da arbejderen er nul og nix i alle samfundsmæssige sammenhænge, er den ægteskabelige magtposition den eneste lillebitte piedestal han kan stille sig selv op på - derfor klamrer han sig til det borgerlige ægteskab. Eller som en »stakkels djævel «formulerer det: »Ingen steder gælder man for noget, ingen steder tæller man med, hverken på fabrikken eller i partiet, eller nogen som helst steder $i$ verden har man noget at skulle have sagt - hvis jeg nu ikke engang i familien skal være herre i huset, vil jeg blæse hele tilværelsen et stykke.«(II: 15). Ægteskabet står i den småborgerlige proletars tilværelse, ligesom ægtesengen står i boligen: midt i værelset, tung og bred, hovedsagen.

Herefter diskuteres forskellige former for sexuelle forhold, samt deres føl- 
ger: uønskede børn. Det beskrives bl.a. hvordan proletarpigerne bliver udsat for en lang række overgreb (f.eks. på arbejdspladsen, af logerende $\mathrm{i}$ den trange bolig,) der gør grænsen til prostitution flydende. Afsnittet er meget kritisk overfor de mandlige arbejderes sexualmoral (hvorimod kvinderne åbenbart er tvunget til passivt at bære deres lidelser?), vel netop fordi det er forhold, hvor der er betydelige spillerum for den enkeltes mulighed for selv at gøre noget ved sagen her og nu. Her bliver Rühles opdragende hensigt meget tydelig. Eksempelvis er her en karakteristisk passage, hvor det om arbejderens forhold til de prostituerede hedder (i Rühles bemærkninger er underforstået den mandlige proletar men hans kritik vil formodentlig i endnu større omfang gælde den kvindelige »småborgerlige « proletar): »Det højeste som proletaren i bedste fald kan præstere til fordel for den prostituerede er en medlidende gestus, en undskyldende skuldertrækning. Hun blev samvittighedsløst forført - hun stod fattig og uden midler på gaden - hun sank dybere og dybere hun blev et offer for omstændighederne. Med disse banale tanke-klicheer, i disse sentimentale talemåder er hele hans medmenneskelighed udtømt. Mere kan han ikke bringe det til. En dyb hjertets træghed forhindrer ham i at gøre mere end at føle medlidenhed og fremsige bekvemme forklaringer. Hans solidaritet bliver ikke aktiveret. Han formår ikke at springe over konventionens grænse, der holder ham tilbage fra en forbeholds- og betingelsesl $\varnothing$ s forbrødring med den prostituerede. Han blir ikke af med borgeren i sit indre « (II: 32).

Rühle viser, hvorledes arbejderklassens ægteskaber i deres idealer og motiver blot stræber efter det bedre borgerskabs livsform, og hvis de materielle betingelser forbedres (manden stiger i grader eller $1 \varnothing n$ ) er målet 1 . kvindens erhvervsophør, 2. bedre og »hyggeligere«bolig, 3. indførsel af typiske småborgerlige vaner. Den gamle socialdemokratiske vandrer-agitator sukker: »Man skal kun een gang have oplevet et af de gængse kaffeselskaber hos socialdemokratiske brugsforeningsuddelerkoner eller en ordentlig gang eftermiddagskaffe (Jause) hos østrigske parti-kvinder, for at forstå, med hvilken dyb inderlighed proletariske kvinder smægter efter saligheden i det borgerlige ægteskabsparadis.«(II: 39). Ægteskabet med dets hjemlige hygge, med dets familieliv, osv. fungerer som værn, tilflugtssted, hvilepunkt - det er og bliver efter sin sociale natur, også i proletariatet, en borgerlig institution.

Fælles for både ægteskabet i borger- og arbejderklasse er, at de skal have børn, også i arbejderklassen gælder det gamle ordsprog: »Ehe ohne Kinder ist halbe Ehe«. Og traditionelt har en næsten kaninagtig frugtbarhed hørt til kendetegnet på det proletariske ægteskab. Rühle diskuterer her sammenhængen mellem fødselstal, børnedødelighed og social placering, hvor fødselstallet er størst i de »laveste« sociale lag - hvilket bl.a. hænger sammen med, at i den værste elendighed er der ud over snapsen ikke anden trøst, end den man kan hente $\mathrm{i}$ ægtesengen. »Konen i sengen er den fattige mands flæskesteg « - som man siger. Yderligere behandles i dette afsnit prævention, abort, skilsmisse. Og Rühle konkluderer: »En omfattende agitation imod fødselstvangen og en righoldig litteratur med krav om bevidst børnetalsbegrænsning har også haft den virkning at ruske op i proletariatet. Ægteskabsproblemet med spørgsmålet om ægteskabsreform, ægteskab uden børn, kammeratskabsægteskab, trepersonersægteskaber, kvindens revolutionering 
og socialisering, abortfriheden, den nye sexualmoral og muligheden for en ny kærlighedskultur hører til nutidens mest omstridte problemer.« (II: s. 60).

Usædvanligt, men helt rimeligt, er det at se, at også »fester, fornøjelser, ønskemål « bliver medtaget i analysen af arbejderklassens hele livssituation. I modsætning til de førkapitalistiske samfund hvor festerne var »nydelsesfester «, bliver de hos de moderne industriarbejdere nødvendiggjort som nervemæssig afspænding fra det ensformige og belastende industriarbejde. Arbejderen har p.g.a. arbejdets karakter behov for aktivitetsskit, ophidselse, beruselse, sensation, som kontrast og kompensation til det ensformige fabriksarbejde. Arbejde og fornøjelser står således i et indre forhold til hinanden.

Med dette udgangspunkt diskuterer Rühle så fænomener som musik og dans, fodboldkampe, seksdagesl $\varnothing b$, boksekampe, osv. samt opkomsten af en underholdningsindustri med biografer, radio, grammofon: »Den kapitalistiske underholdningsindustri har meget dygtigt vidst at tage hensyn til den indre konstitution hos proletariatet og de erhvervsaktive dele af borgerklassen. Den har skabt en underholdningsforretning, har indført metoder til underholdning, adspredelse og selskabelighed, som er så fuldkomment tilpasset situationen hos de udmattede, overanstrengte nervøse og opstemte, derfor nydelsesbegærlige og afspændingskrævende arbejdere og funktionærer, at den på den korteste tid har slået alle overleverede former for rekreation af marken. Biograf, grammofon og radio har revet monopolet på de moderne fornøjelser til sig, som geniale kompositioner af teknik, underholdning, kunst og psykologi.« (II: 290). Underholdningsfilmene er netop sådant et produkt, hvor man ikke behøver tænke med selv, alt er gjort så letfatteligt, man skal bare sidde der, uden at der stilles krav til fornuft, hukommelse, koncentration eller ansvarlighed; selvom film også - som f.eks. S. Eisensteins - kan have overordentlig værdi som dannelsesmiddel.

Hermed kommer Rühle ind på overvejelser over proletariatets forhold og holdning til kunst. »Proletariatet er netop en særlig klasse, men - som vi ved - fuldstændig kulturbundet til borgerskabet, derfor også på sine ideologiske områder fuldstændig udleveret til indflydelse fra den borgerlige idé- og følelsesverden. Ligesom det ikke har nogen egen kultur, besidder det heller ingen egen kunst.«(II: 296). Der eksisterer altså ingen »proletarisk kunst « i det borgerlige samfund - det, der bliver kaldt således, er: 1. kunst der skildrer proletarisk miljø, 2. kunst lavet af personer med proletarisk klassebaggrund, 3 . kunst med en revolutionær, propagandistisk tendens. Men fælles for alle 3 grupper er, at de betjener sig af traditionelle borgerlige stilmidler og at kunsten absolut er individualistisk - ingen nok så fordringsfuld, nok så selvbevidst »proletarisk « kunst kommer udover den traditionelle heraldik i den borgerlige revolutionsromantiks fiduskunst. »Egen skabende aktivitet på kunstens område kan proletariatet ikke komme frem til indenfor rammerne af den borgerlige kultur og samfundsorden. Dertil er det nødvendigt, at kunsten har ophørt med at være et særområde af tilværelsen, et reservat for undtagelsesmennesker, en præstation fra særlige personligheder. Den må atter blive et hverdagsanliggende, indgå $\mathrm{i}$ det daglige arbejde, i det almindelige værk, i massernes liv, ikke mere være en individuel akt, men social befrugtelse og fylden med liv.« (II: 301).

Efter Rühles opfattelse er det hidtil kun lykkedes arbejderne at skabe een 
festdag med proletarisk karakter, nemlig 1. maj, og han har derfor en meget grundig gennemgang af dennes historie - og forfald.

Hvis man ser på arbejderens nød, snævre livsrammer, hans tilværelses håbløshed, ville det ikke være mærkeligt, hvis han søgte at kompensere for sine mangler gennem højtflyvende $\varnothing$ nsker og forventninger. Men dette er imidlertid kun sjældent tilfældet. Da proletariatets situation er millioner af menneskers lod, affinder de fleste sig med den som noget, man ikke kan flygte fra. Derfor er det, at arbejderens krav til livet er så beskedne - ligesom hans virkelighed bevæger også hans ønskeliv sig indenfor grænserne af den yderste tilbageholdenhed og bornerthed. En sådan beskedenhed opfattes af mange som en dyd - hvorimod f.eks. Lasalle har betegnet denne »fordømte mangel på behov« som en af hovedhindringerne for den proletariske emancipation. Rühle gennemgår forskellige arbejdergruppers ønsker og mål for tilværelsen og de er i sandhed beskedne: lidt bedre $1 \varnothing \mathrm{n}$, lidt småforbedringer i fritiden, stræben efter højere stillinger, osv. Ynkeligheden i deres slavetilværelse modsvares af ynkeligheden i deres idealtilværelse og $\mathrm{i}$ deres fantasi. »I alle trængslerne og længslerne, forhåbningerne og målene den småborgerlige verdens udtrykte billede. Ingen steder en storslået higen, en dristig sætten alt på et kort. Ingen selvbevidst gestus, ingen mod til egen udformning af tilværelsen. Den triste konstatering: overalt forfuskede borgere, spidsborgere der blir siddende på plads, glemte aspiranter til pensionens behageligt-bekymringsløse sofa.« (II: 328).

Endvidere behandles arbejderens behov for at bo og indrette sig smukt og bekvemt - behov som deres arbejdsforhold taget i betragtning er forståelige.
Problemet er blot, at de vælger de forkerte midler - de forveksler deres egen verden med småborgerens. Her kritiseres alt det simili og småborgerlige lort proletarerne fylder deres bolig med. Særlig tilstedeværelsen af et »regulatorur« eller et »vertiko« (et skab) kan hidse Rühle op - de må åbenbart dengang have haft samme status som 3-2-1 sofa-sættet har idag.

Men proletaren stræber altid udefter. »Han blir fortæret af lægnsel efter et bedre liv, og han kæmper for det. Men når han har skabt det, lander han næsten altid i et småborgerhjem med fin stue, hvide gardiner, tæppe på sofaen, en grammofon, en frugtskål på bordet, et vertiko og et regulatorur.« (II: 335).

\section{Veje t.il befrielse}

Dette hovedafsnit, som desværre ikke holder niveau med de $\varnothing$ vrige, har 3 underafsnit: $\emptyset$ konomisk, social og ideologisk befrielse. I afsnittet om $\varnothing$ konomisk befrielse behandles dels nogle almene tendenser i produktionens udvikling, (kapitalernes koncentration, taylorisering af arbejdsprocesserne), dels socialiseringsfors $\emptyset$ gene $\mathrm{i}$ hhv. den russiske og den tyske revolution. Det er jo skrevet med den tyske revolutions nylige nederlag $\mathrm{i}$ baghovedet og Rühle konkluderer således på dette afsnit: »Det er bemærkelsesværdigt og betegnende, at de tyske arbejdere knap har reageret på, at alle planer og fors $\varnothing \mathrm{g}$ på en socialisering har slået fejl. Måske skal man anse dette som et symptom på, at de inderst inde var fuldstændig udeltagende $\mathrm{i}$ alle disse diskussioner, projekter og eksperimenter. De havde aldrig beskæftiget sig alvorligt med magtovertagelsens problem, havde aldrig grundigt reflekteret over den praksis, der skulle føre den kapitalistiske vareøkonmi over i en socialistisk behovs $\varnothing$ konomi. Alt for fanget $\mathrm{i}$ aktuelle interesser, for lidt $\mathrm{i}$ det 
samfundsmæssige $\emptyset$ konomiske apparats mekanisme og funktioner, alt for fanget i den bekvemme opfattelse af et automatisk forløb af overgangsprocessen, havde de i deres socialistiske tænken behandlet kravet om ekspropriation alt for slagordsagtig og set på indretningen af behovsøkonomien med al for utopisk naivitet, til at de kunne komme frem til en eksakt stillingtagen og et konkret forhold til disse opgaver. De stolede på deres føreres dygtighed og intelligens.« (II: 380).

Den »objektive « forberedelse af socialismen er et $\phi$ konomisk spørgsmål og den »subjektive« fuldbyrdelse af overgangen er et politisk spørgsmål; proletariatet må udvikle og gennemføre denne politik. På dette punkt står Rühle altså her på et helt traditionelt II. Internationalestandpunkt.

I afsnittet om »social befrielse« drejer det sig hovedsageligt om en gennemgang og kritik af kamp- og organisationsformer. I udgangspunktet lægger Rühle sig - mere eksplicit her end andre steder i bøgerne - i forlængelse af Kausky, Hilferding, Lenin med deres forskellige teser om imperialismen som kapitalismens sidste stadie, om monopolerne, arbejderaristokrati-opfattelsen, bestikkelse af arbejderne gennem socialpolitikken, osv.

Der fremføres så en kritik af socialdemokratierne og fagforeningerne, hvor det hedder at disse traditionelle organisations- og kampformer har mistet deres samfundsmæssige begrundelsessammenhæng og må erstattes af nye former. Rühle gennemgår de ansatser han ser til sådanne »nye « arbejderbevægelser, nemlig I.W.W. i USA, rådene i den tyske revolution og »shop stewart « bevægelsen i dens tidlige faser lige efter krigen i England. Det nye ved disse organisationsformer er, at de baserer sig på arbejdernes selvstændige aktivitet og initiativer, på selvforvaltning i stedet for ledere og burokrati. Disse nye formationer indebærer et grundlæggende opgør med repræsentationsprincippet. »Masserne siger ikke længere: førerne skal hjælpe os! men derimod: vi vil hjælpe os selv! De anser ikke længere fortidens taktiske metoder som tilstrækkelige til nutidens krav. Dette ikke blot indenfor $\emptyset$ konomien, i kampzonen mellem arbejdsgivere og lønarbejdere, på fagforeningsbevægelsens felt, men også i politikken.« (II: 402).

Dette føres videre i et opgør med parlamentarismen. De forskellige revolutionsfors $\varnothing \mathrm{gs}$ nederlag har modnet den erkendelse i proletariatet, at den »politiske « kamp altid kun udmøntes i magtforskydninger, den fuldbyrder sig på det allerede givne grundlag. Det betyder, at organisationer med en taktik der støtter sig på borgerlig politiks metoder, nødvendigvis vil ende med et kompromis med den bestående borgerlige $\emptyset$ konomi og statsmagt. Dele af arbejderklassen erkendte, at den proletariske revolution ikke kunne gennemføres med borgerlige metoder, men krævede sine egne selvstændige kampformer og taktik.

Det drejer sig således ikke blot om en kamp om målet, men også om midlerne til befrielse. I første omgang er proletariatet henvist til de midler, de overtager fra den borgerlige politiks arsenaler, og de omfatter først og fremmest: »... i statslig henseende republikken på grundlag af parlamentarismen, i organisatorisk henseende centralisme $\mathrm{i}$ form af partiet, i taktisk henseende forhandlings-metoden med kompromis'et som effekt.« (II: 415). Gennem langvarige kampe må proletariatet tilkæmpe sig sine egne midler og metoder til en selvstændig politisk kultur.

Overgangen til socialisme må praktiskt være arbejdernes egen handling og den farligste illusion er at tro, at man automatisk kan vokse ind i socialismen, 
så at sige i søvne. Men at fastholde revolutionen kræver den bredeste massebasis og den revolutionære beslutsomhed i et omfang, der kun er muligt indenfor rammerne af rådssystemet, rådssystemet på grundlag af virksomhederne. »Derfor er rådssystemet den givne revolutionære formation for proletariatet. Det er den mest magtfulde masseorganisation til erobring af magten og til at slå borgerskabet ned med. Kun det frembyder muligheden for at sikre revolutionens politiske resultater og at gennemføre den økonomiske, politiske og kulturelle nyopbygning.« (II: 417).

Rühle slutter med en diskussion af hvad proletariatets diktatur er og begrunder dets nødvendighed ud fra truslen om kontrarevolutionen. Proletariatets diktaturs væsentligste opgave er sprængningen og overvindelsen af den borgerlige stat. Og han konkluderer »Proletariatet der er kommet til magten ophæver ved hjælp af diktaturet privatejendommen, vareproduktionen, klasseforholdet, privilegierne, statens tvangsmagt overfor arbejderklassen, parlamentet og alle borgerskabets magtorganer. I stedet for den gamle orden grundlægger det en ny på grundlag af rådssystemet.« (II: 422).

I det sidste underafsnit om »ideologisk befrielse « er der ikke så meget at hente. Det drejer sig først og fremmest om forholdet mellem samfundets basis og individernes bevidsthed og Rühle argumenterer kraftigt for, at den ideologiske opdragelse ikke er noget, der kan udsættes til efter revolutionen. Ligeledes skal man heller ikke tro, at der med den revolutionære omvæltning af basis automatisk indfinder sig en ny ideologi. Rühle gennemgår derefter forskellige stadier $i$ det »socialistiske menneskes « udvikling på mig virker dette sidste afsnit som noget af et anti-klimaks. Alfa og omega er imidlertid argumentationen for nødven- digheden af oplysning og ideologisk opdragelse: »Udviklingen er idag nået til et punkt, hvor overvindelsen af det kapitalistiske system i menneskene, afkapitaliseringen af ideologien, afneurotiseringen af sjælene træder ind i stadiet af en aktuel opgave. Løsningen af denne opgave synes at være så meget mere påtrængende, som klassekampens rent politiske organer stadigt mere åbenbart svigter, ja begynder at stille sig tilfreds med tomgang. De kulturelle organer bliver stadigt mere uforbeholdent stillet i de kontrarevolutionære hæmningers og opbremsningers tjeneste. « (II: 438).

Hermed er hovedlinierne i Rühles gennemgang af proletariatets kulturhistorie skitseret og forskellige udvalgte dele er refereret. Der skulle således være givet indtryk af hvor mange forskellige sider af arbejderklassens daglige liv det lykkes Rühle at få med. Mig bekendt findes der ingen andre fremstillinger, der får så meget bredde $i$ behandlingen af arbejdertilværelsens totalitet. Jeg finder denne bredde i perspektivet positiv i sig selv, idet - uanset hvordan Rühle indløser analysen i dybden - der hermed er fors $\varnothing$ gt opstillet en ramme for totalanalysen af arbejderens situation, som man så selvfølgelig må forholde sig til, kritisere, ændre med ændrede historiske forhold, supplere, osv., men der er altså her skitseret noget man kan tage udgangspunkt i.

»Kulturhistorien « er nu præcis 50 år gammel, men den er skrevet på en meget inspirerende og provokerende måde, der hele tiden får læseren til at tænke over disse mellemliggende 50 års udvikling og forandring. De utroligt store forandringer i dagliglivet, der netop forsvinder i de evindelige dagligdage, kommer tydeligt frem gennem denne perspektivering. Den træghed og ubevægelighed som vi længselsfulde socialister oplever 
i dagligdagen, forsvinder til en vis grad, ved en forståelse af den voldsomme dynamik, som faktisk har kendetegnet de sidste 50 års kapitalisme - vor kollektive hukommelse synes at være lige så kort som vort fremtidsperspektiv. Inden revolutionen skydes helt ud i den fjerneste fremtid, skal man altså ikke overse, at 10 år sagtens kan føre fra et samfund til et andet!

En tredie god ting ved »Kulturhistorien« er, at den viser, at man godt som intellektuel kan beskæftige sig med de »rigtige « arbejdere og deres forhold på en måde, der både er solidarisk og kritiserende - man behøver altså ikke absolut ende i den klæge, arbejderistiske herokult. Ganske vist kan Rühles kritiske irettesættelser nogen steder være lige lovlig moraliserende, men på den anden side har han fat i mange rigtige forhold, som stadigvæk er ligeså kritisable og som man heller ikke selv kan undgå at måtte tage til sig. I forhold til den aktuelle, meget omfattende interesse i »privatsfærens« forhold - som vi jo også selv tager op $\mathrm{i}$ dette nummer - der ofte fortaber sig $\mathrm{i}$ en perspektivl $\phi s$ opslugthed af de sociale »mikroprocesser«, er Rühles fastholden af store sammenhænge og perspektiver ofte eksemplarisk. Jeg synes der for tiden blandt mange socialister er en tendens til, blot at ville forstå, hvorfor forholdene er, som de er, men ingen trang til at kritisere og lave om, og dette kommer særligt tydeligt frem i beskæftigelsen med »dagliglivet « og dets forhold - noget man så får at vide, skal forstås og forlares ud fra samfundets krisetilstand!

Men »Kulturhistorien « har bestemt også sine problematiske sider. Dens største problem er nok de mange selvmodsigelser i den teoretiske konstruktion, der skal bære fremstillingen. Rühle er dels dybt rodfæstet i den Kautskyanske marxisme fra II. Internationales periode, dels har han senere i efterkrigstiden udviklet radikale rådskommunistiske tankegange, som bryder med de gamle, men uden at det har ført til en kritik af den oprindelige teori. Lenin er et samtidigt og fuldstændigt parallelt tilfælde: begge accepterer ukritisk Kautsky og Hilferdings teorier fra før krigen og kan derfor ikke gøre andet end at beklage, at disse store marxister har svigtet politisk - og dermed svigtet deres eget oprindelige grundlag - og er blevet opportunister. Til »Kulturhistoriens « undskyldning tjener til dels, at bd. II ikke var færdiggjort af Rühle ved hans $\mathrm{d} \varnothing \mathrm{d}$ og at udgivelsen altså er tilrettelagt af andre.

Når hhv. Kautsky, Lenin, og Rühle kan dele fælles grundlæggende samfundsopfattelse og alligevel, på grundlag af denne forståelse, trække helt forskellige konklusioner hvad angår revolutionsopfattelse, strategi og taktik, må det vise hen til indre modsigelser i disse teorier - og de findes altså i rigt mål også hos Rühle. Samtidig er han i perioden meget påvirket af psykologen Alfred Adler og mange af Rühles overvejelser forekommer idag at være plat psykologiserende. Om dette siger Paul Mattick: »Det var uundgåeligt, at den psykologiske mode også greb arbejderbevægelsen. Men hele denne bevægelses forfald blev afsløret gennem dens fors $\varnothing \mathrm{g}$ på at bruge den borgerlige psykologis og sociologis teorier til en kritisk undersøgelse af dens egne teorier, istedet for at anvende den marxistiske teori til kritik af den nye borgerlige videnskab. Bag denne indstilling skjulte sig en voksende mistro til marxismen - en følge af den russiske og tyske revolutions svigten. Men bagved skjulte sig også den manglende kapacitet til at gå ud over Marx på en marxistisk måde. Ulykkeligvis, set fra vort standpunkt, var Otto Rühle en af de første, der klædte de marxistiske ideer i den borger- 
lige sociologis og psykologis nye sprog. Den materialistiske opfattelse af historien blev nu til »sociologi «, for såvidt den beskæftigede sig med samfundet, »psykologi« for såvidt den beskæftigede sig med individdet.« (»Otto Rühle ... op.cit. s. 34).

At Rühles teori selv er fuld af modsigelser, er ikke det samme som, at den begriber virkeligheden som modsigelsesfyldt. Selvfølgelig gør han det til en vis grad (klassemodsigelser, modsigelser mellem produktionsforhold og produktivkræfter, osv.), men på det mere konkrete plan bliver forholdene fremstillet for »entydige« og dermed ubevægelige: enten er der revolution eller også er arbejderne fuldstændig uinteresserede »småborgere «; de modsigelsesfyldte sociale (mikro)processer, som fører fra det sidste mod det første, og som jo netop må være en »kulturhistories « fornemste objekt, bliver ikke klart nok behandlet.

Endelig kunne jeg godt have tænkt mig en mere pointeret sondring mellem kapitalistiske og førkapitalistiske bestemmelser, for på denne måde at præcisere, hvad et kapitalistisk samfund indebærer for arbejderens tilværelse, samt også nogle differentieringer (»faser «) indenfor den kapitalistiske udvikling andet end opdelingen mellem »konkurrence« - og »monopolkapitalisme« som slet ikke forbindes til proletariatets kultur. En fundamental måde for Rühle at tænke på, er at lægge den grundlæggende klassemodsigelse mellem arbejdere og kapitalister ind, dels i forholdet mellem arbejderne indbyrdes (i arbejdet, i ægteskabet, i forhold til børnene, osv.) og dels ind i selve "personligheden«. For Rühle er arbejderen kun rigtig proletar på fabrikken, i sit hjem er han »borger«, og han taler ligeledes ofte om »borgeren inde $\mathrm{i}$ arbejderen« (den indre svinehund?). Men han forholder sig ikke til, om disse analogier er formuleringer af den manglende specifikke samfundsmæssiggørelse af »reproduktionssfæren « og »personligheden «, eller om disse former skal betragtes som fuldt udviklede, egentlige kapitalistiske formbestemmelser.

Der er ingen tvivl om, at Rühle selv har set $\sin »$ Kulturhistorie« som middel til opdragelse og oplysning af proletariatet, den er primært skrevet for at ændre holdninger og indstillinger $\mathrm{i}$ arbejderklassen og i denne synsvinkel fungerer den sikkert efter hensigten. Men denne »oplysningsstrategi « som led i en revolutionær strategi, behandles ikke selv i bogen. G. Mergner formulerer implicit enhver »oplysningsstragegis « grundtese, idet han diskuterer Rühles holdning til spaltningen af Socialdemokratiet under 1. verdenskrig. Rühle er modstander af en »enhedsgrød « af heterogene tendenser, som blot vil udgøre en »form- og væsensløs sump« uden principper og karakter, hvorimod han kræver et verdensanskuelses- og masseparti opbygget på klare principper og holdninger. »Enheden af handling og tænken vil han se sikret i enheden af de anskuelser der bestemmer handlingerne." (Mergner, op.cit. s. 84). Det centrale spørgsmål til denne opfattelse bliver derfor: hvad bestemmer anskuelserne, hvis de lader sig ændre gennem »oplysning «? Og netop i svaret på dette problem er der ikke så meget at hente $\mathrm{i}$ »Kulturhistorien « - dér konstateres forskellige anskuelser og holdninger stort set blot og deres »borgerlighed « kritiseres.

P. Mattick kommenterer Rühles oplysningsstrategi således: »Flere og flere folk, der udgik fra den antagelse, at de »objektive betingelser « var modne til revolutionen, forklarede dens udebliven med »subjektive faktorer«: med arbejdernes 
manglende klassebevidsthed og forståelse. Denne mangel må selv atter forklares ud fra de »objektive betingelser «, da proletariatets utilstrækkelighed utvivlsomt resulterede af dets særlige position i kapitalismens samfundsmæssige forhold. Nøden til at begrænse alle aktiviteter til opdragelsen, blev gjort til en dyd: udviklingen af klassebevidsthed hos arbejderne gjaldt som den mest påtrængende opgave. Dog overbeviste den gamle socialdemokratiske trosbekendelse »viden er magt« ikke længere, da der ikke fandtes nogen direkte sammenhæng mellem denne viden og dens anvendelse.« (op.cit. s. 32).

Disse indvendinger skal imidlertid ikke afholde nogen fra at læse »Kulturhistorien«. Lader man være med at blive irriteret over det lidt tidsbundne, lidt patetiske sprog og den lidt skolemesteragtige stil er det en god oplevelse. Bøgerne er fyldt med sammenhænge, overblik, spændende perspektiver, fordomsfri stillingtagen, klare iagttagelser og kritiske overvejelser. Og så er det mange steder næsten lige så sjovt som at læse Marx.

Finn Dam Rasmussen

\section{NOTER}

1. Udover de to der bliver omtalt her i anmeldelsen kan f.ex. nævnes følgende af Rühles skrifter:

Schriften, Rowohlt, 1971.

Baupläne für eine neue Gesellschaft, Rowohlt 1971.

Karl Marx, Editiora Queimada, Haarlem 1974.

Von der bürgerlichen zur proletarischen Revolution. Karin Kramer Verlag, 1970.

Iøvrigt kan henvises til H.M. Bock: Geschichte des »linken Radikalismus« in Deutschland. Ein Versuch. Suhrkamp 1976, hvor der findes en omfattende Rühle-litteraturliste med oplysninger om reprint af de enkelte titler.

2. F.eks. leder man forgæves efter oplysninger om Otto Rühle i P. Vranicki: Geschichte des Marxismus I \& II, Suhrkamp 1972.

3. Mere om O. Rühle kan man finde hos

G. Mergner: Arbeiterbewegung und Intelligenz, Starnberg 1973 (som er den mest omfattende behandling af Rühle - omend noget slatten.)

F.G. Herrmann: Otto Rühle als politischer Theoretiker, i Internationale wissenschaftliche Korrespondenz nr. 17 \& 181972.

P. Mattick: Otto Rühle und die deutsche Arbeiterbewegung, i Spontanität und Organisation, Suhrkamp 1975).

H. Jacoby: Forord i bd. 2 af »Kultur und Sittengschichte ...«

4. Det er et gennemgående tænkemønster hos Rühle, at borgerskabets klassespecifikke adfærd og måder at forholde sig på overfor arbejderklassen fremstår som givne »identifikationsfigurer« indenfor arbejderklassen selv jvnf. f.ex: »Klassesamfundets karakteristiske billede, skemaet ovenpå-nedenunder gentager sig i ægteskabet. Kønnenes placering ved det ægtes- 
kabelige samleje bliver et drastisk symbol. Ligesom bourgeoisie og proletariat udgør det borgerlige smafund, udgør mand og kvinde det borgerlige ægteskab.« (II: 5).

5. Rühles kone, som han samarbejdede med, har bl.a. skrevet: Alice Rühle-Gerstel: Die Frau und der Kapitalismus, der er kommet i reprint hos Verlag Neue Kritik, Frankfurt 1971.

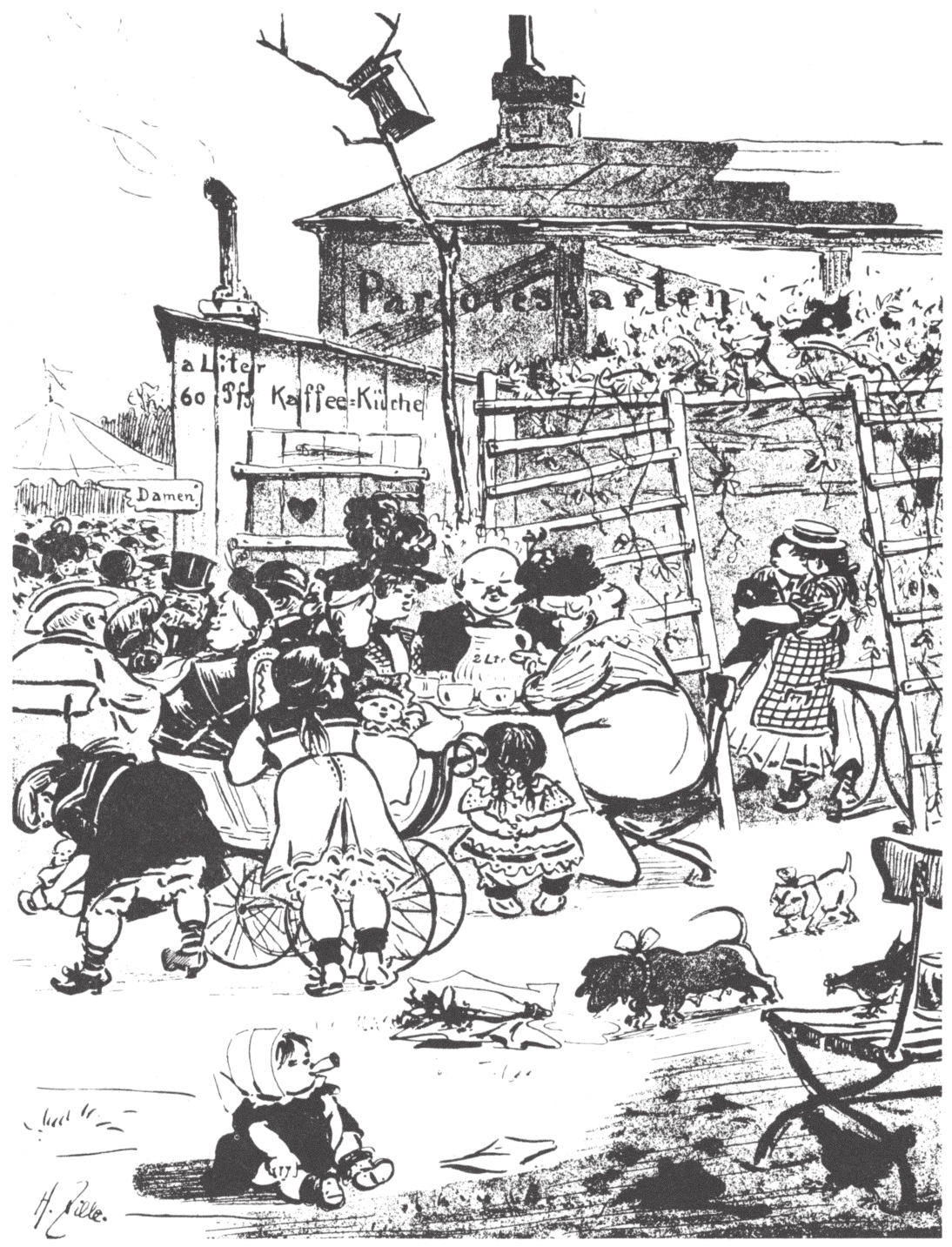

»DEN UPOLITISKE ARBEJDERS SØNDAGSFORNØJELSE«

Karikatur af Heinrich Zille fra Otto Rühles: proletariatets kulturhistorie. 